\title{
DOI https://doi.org/10.30525/978-9934-26-181-7-37
}

\section{ВНУТРІШНЬО ПЕРЕМІЩЕНІ ОСОБИ В УКРАЇНІ: ГЕНДЕРНИЙ ВИМІР}

\author{
Малярчук Н. Г. \\ кандидат історичних наук, \\ дочент кафедри сочіального управління \\ Донецький державний університет управління \\ м. Маріуполь, Донецька область, Украӥна
}

Станом на 6.07.2021 р. в Україні взято на облік 1473650 осіб, які, після анексії Росією у 2014 р. Криму та окупації частини Донбасу, були вимушені залишити свої домівки й переїхати на підконтрольні українському уряду території [7]. Оскільки розв'язання проблеми Криму та Донбасу може затягнутися на довгі роки, то ефективна робота з ВПО, сприяння їхній адаптації та інтеграції у приймаючі громади, є одним 3 пріоритетних завдань як державних інституцій України, так і місцевих громад загалом. На особливу увагу в цьому контексті заслуговують жінки, які згідно офіційної статистики становлять серед ВПО абсолютну більшість - $59 \%$ [8]. Варто також зважати на те, що негативний вплив вимушеного переселення на жінок $є$ значно більшим, ніж на чоловіків, оскільки українське суспільство, на жаль, не позбавлене проявів гендерної дискримінації. Тому в роботі з ВПО обов'язково потрібно враховувати гендерний аспект.

Мета роботи: розглянути гендерні аспекти адаптації та інтеграції ВПО у приймаючих громадах, виділити особливості проходження основних етапів адаптації жінками-ВПО, окреслити основні проблеми, з якими вони стикаються.

Вимушене переміщення відрізняється від звичайної міграції перш за все тим, що, як правило, відбувається зненацька, під впливом зовнішніх причин, через реальну загрозу життю і благополуччю, що фактично не залишає вибору, змушуючи людей раптово покидати свої домівки. Відсутність достатньо тривалого передадаптаційного періоду, під час якого формується внутрішня мотивація до переїзду, здійснюється попередня підготовка, роблять його надзвичайно стресовим [1, с. 14, 25]. Негативним наслідком вимушеного переміщення $є$ фактичне руйнування «життєвих проектів» ВПО, передумовою відновлення яких є успішна адаптація переміщеної особи на новому місці проживання та подальша інтеграція в приймаючій громаді [4, с. 22]. 
Адаптація ВПО в приймаючих громадах відбувається поступово й включає такі етапи, як: соціально-побутова, економічна, комунікативна, регулятивна адаптація, а також етап самореалізації [10]. Соціальнопобутова адаптація передбачає пристосування до нових умов життя, налагодження побуту, поліпшення психологічного самопочуття ВПО. Економічна - працевлаштування, отримання стабільного джерела прибутку. Непоодинокими є випадки, коли саме жінкам-ВПО доводиться брати на себе відповідальність за соціально-побутову та економічну адаптацію родини. Хоча під «домогосподарствами очолюваними жінкою» зазвичай розуміють сім'ї де чоловік відсутній, на практиці так відбувається не завжди. Іноді, в силу певних обставин, жінка виступає фактичною очільницею домогосподарства навіть при наявності чоловіка у родині. Основною причиною такого становища може бути те, що чоловікам більш складно погодитися на гірше оплачувану роботу, ніж була в них удома, або змиритися з пониженням їхнього посадового статусу. Жінки ж, в більшості своїй, беруться за будь-яку роботу, що може дати потрібні кошти для забезпечення сім'ї і тому перетворюються на фактичного голову родини, хоча чоловіки не завжди визнають це й розглядають економічну активність жінок, як виконання властивої їм функції опіки та догляду за членами родини [1]. Водночас, через гендерні стереотипи, безробітні чоловіки-ВПО не завжди готові виконувати хатню роботу замість працюючої дружини, вважаючи це «жіночою справою» [4, с. 16-18]. Отже, у такій ситуації становище жінки погіршується, вона відчуває подвійне навантаження, намагаючись поєднати ролі «годувальниці родини» і господині дому, «берегині родини».

Згідно $з$ соціологічними дослідженнями жінки-ВПО перебувають у економічно-вразливішому стані, ніж чоловіки: вони втричі частіше за них опікуються багатодітними родинами; майже удвічі частіше проживають у малозабезпечених родинах; на 9\% частіше належать до сімей, які перебувають у складних життєвих обставинах; відчувають більше навантаження і відповідальність щодо виховання й забезпечення неповнолітніх дітей $(27,1 \%$ чоловіків проживає разом 3 дітьми до 18 років, тоді як жінок - 41,6\%) [5, с. 3].

Вирішення соціально-побутових та економічних проблем $є$ важливою умовою подальшої інтеграції жінок-ВПО у приймаючі громади. На думку багатьох 3 них головною перепоною на цьому шляху $є$ відсутність постійного житла, що заважає налагодити соціальні зв'язки, знайти стабільну роботу, або розпочати підприємницьку діяльність. У жінок значно менше можливостей орендувати житло, або придбати його, ніж у чоловіків. Хоча в нормативно-законодавчих документах відсутня 
дискримінація за статтю в оплаті праці, середня заробітна плата жінок в Україні дорівнює близько 70 \% зарплатні чоловіків [3, с.106]. За даними Всесвітнього кластера $з$ питань житла, станом на травень 2016 року жінки становили 73 \% від загальної кількості ВПО, що мешкали у центрах для колективного проживання, які у багатьох випадках погано пристосовані для проживання, особливо в холодну пору року [9]. Це пов'язано з тим, що оренда квартири вартує більше, ніж щомісячна адресна допомога ВПО для покриття витрат на проживання та оплату житлово-комунальних послуг, а іноді навіть більша за зарплату жінки. Базовою соціальноекономічною проблемою можна вважати й проблему з працевлаштуванням, дослідження показують, що переважна більшість (79 \%) безробітних-ВПО, котрі активно шукають роботу, це жінки. Серед респондентів, які повідомили про те, що стикалися $з$ труднощами в пошуку роботи, теж переважають жінки [6].

Але повноцінна адаптація передбачає не лише матеріальне забезпечення, вона має й психологічний бік, що включає в себе комунікативну та емоційну складові. Комунікативна адаптація жінок-ВПО потребує пристосування їх до нових взаємозв’язків і взаємостосунків в приймаючій громаді, включення в нове соціальне середовище. Поведінка жінок більше, ніж чоловіків спрямована на формування позитивного емоційного настрою до себе з боку місцевих жителів. Вони швидше, ніж чоловіки встановлюють контакти 3 членами приймаючої громади, створюють ініціативні групи, громадські об’єднання, які співпрацюють 3 місцевою владою, представниками приймаючих громад [2]. Жінки емоційніші, більше потребують спілкування й у кризовій ситуації частіше звертаються за допомогою (до колег, сусідів, родичів, соціальних служб), ніж чоловіки.

Серед психологічних проблем жінок-ВПО, які заважають адаптації, можна виділити такі: стрес від вимушеного переміщення; брак досвіду соціальної та географічної мобільності; розрив тісних зв'язків із близькими родичами та сусідами; стан людини, що не живе вдома; життя у стані невизначеності; проблема «розірваної родини»; загроза розпаду сім'ї під тиском соціально-побутових та економічних проблем; відчуття провини перед дітьми за неможливість забезпечити їм кращі умови життя тощо.

Наступні етапи адаптації - регулятивний та етап самореалізації, пов'язані з формуванням у жінок-ВПО, під впливом змін, що відбулися в житті, нових якостей характеру, розкриттям прихованих раніше рис особистості, задоволенням потреб у безпеці й повазі. В українських ЗМІ можна знайти багато прикладів історій, коли жінки у важких умовах вимушеного переміщення зуміли стати агентками змін власного життя, 
кардинально змінивши професію, започаткувавши власний успішний бізнес тощо.

Таким чином, на відміну від чоловіків стратегії адаптації жінок відрізняються більшою гнучкістю. Часто жінки-ВПО відчувають подвійне навантаження, оскільки вимушені працювати, взявши на себе обов'язок «очільниці домогосподарства» та виконуючи усю хатню роботу. Більш швидкій адаптації жінок в приймаючій громаді сприяє властива їм здатність встановлювати зв'язки та емоційний контакт 3 місцевими мешканцями. Водночас, емоційність жінок має і зворотній вплив на ефективність їхньої адаптації, оскільки розрив тісних зв'язків із близькими родичами, сусідами пригнічує їх більше, ніж чоловіків. Головними перепонами, що постають на шляху адаптації жінок-ВПО до нових умов життя та інтеграції їх у приймаючих громадах $є$ як психологічні проблеми, пов'язані перш за все зі стресом від вимушеного переселення, розірванням звичних соціальних зв'язків, невизначеністю майбутнього, так і соціально-економічні - погіршення умов життя й відсутність реальних перспектив їхнього покращення, 3 огляду на проблеми з працевлаштуванням, браком постійного житла та зайнятістю жінок у низькооплачуваних галузях економіки.

\section{Лiтература:}

1. Бритвина И. Б. Гендерная детерминация адаптации вынужденных мигрантов: социологический анализ : автореф. дис. ... д-ра социол. наук : 22.00.06. Екатеринбург, 2006. 39 с.

2. Внутрішньо переміщені особи та приймаючі громади: розбудова толерантності через діалог. Успішні історії. Український жіночий фонд. Фонд Чарльза Стюарта Мотта. 2018-2019. 24 с.

3. Гендерні перетворення в Україні. Київ : АДЕФ-Україна, 2007. $165 \mathrm{c}$.

4. Гендерний вимір внутрішнього переміщення: світовий досвід $\mathrm{i}$ ситуація в Україні. Методичне керівництво. Харків, 2020. 74 с.

5. Звіт про гендерний аналіз результатів Всеукраїнського опитування щодо дотримання прав ВПО. За підтримки Програми розвитку 00Н в Україні та Міністерства закордонних справ Данії. 2017. $24 \mathrm{c}$.

6. Майже 80 відсотків ВПО, котрі шукають роботу, - це жінки: результати опитування. Урядовий портал. URL: https:// www.kmu.gov.ua/news/majzhe-80-vidsotkiv-vpokotri-shukayut-robotu-cezhinki-rezultati-opituvannya 
7. Міністерство соціальної політики України. Внутрішньо переміщені особи. URL: https://www.msp.gov.ua/news/20309.html

8. Національний план дій з виконання резолюції ради безпеки $\mathrm{OOH} 1325$ «Жінки, мир, безпека» на період до 2025 року. URL: https://zakon.rada.gov.ua/laws/show/1544-2020-\%D1 \%80\#Text

9. Розбудова миру: нехай жінки скажуть своє слово / OSCE: веб-сайт. URL: https://www.osce.org/uk/ukraine-smm/257256

10. Тюптя Л.Т., Іванова І.Б. Соціальна робота: Теорія і практика. К.: ВМУРОЛ «Україна», 2004. 408 с. URL: https://pidru4niki.com/11151212/ sotsiologiya/sotsialna_adaptatsiya_reabilitatsiya

\title{
DOI https://doi.org/10.30525/978-9934-26-181-7-38
}

\section{СФЕРИ СУСПІЛЬНОГО ЖИТТЯ ТА ЇХ ЗНАЧЕННЯ ДЛЯ ПОДАЛЬШОГО ІСНУВАННЯ ЛЮДСТВА}

\author{
Тімашова В. М. \\ доктор політичних наук, \\ професор кафедри міжнародних відносин та гуманітарних студій \\ Національний педагогічний університет імені М. П. Драгоманова \\ м. Київ, Україна
}

У пропонованих тезах ми обираємо, на нашу думку, найважливіші сфери суспільного життя, в яких відбуваються процеси, що здатні вплинути на подальше існування або загибель людства. В епіцентр нашої уваги потрапляють політична, екологічна, інформаційна, соціальна та духовна сфери суспільного життя. У зазначених сферах ми виділяємо ключові проблемні маркери, на які найперше потрібно звернути увагу 3 метою розроблення стратегій виживання і вжиття необхідних заходів для їх реалізації.

Історія людської життєдіяльності є історією пошуку гармонії сфер суспільного життя, органічної єдності людини і природи, людини й суспільства, людини і людини. Протягом усього історичного часу відбувається процес осмислення, конституювання (встановлення змісту, визначення складу, особливостей) поняття сфер суспільного життя i процесів, що там відбуваються.

Сьогодні актуалізується пізнавальний інтерес до так званої «піраміди потреб Маслоу», яка - у значно оновленій проекції - визначає основні 